\title{
PRIVATE FOUNDATIONS AND THE TAX REFORM ACT OF 1969
}

\author{
HOMER C. WADSWORTH*
}

Seven years have passed since the passage of the Tax Reform Act of $1969,{ }^{1}$ and yet no one really knows what its total effects have been on private foundations or upon charitable giving in general. Perhaps the only thing about which one can be quite certain is that those who elect to establish new private foundations do so for other than tax reasons. Almost all the tax incentives for creating new foundations were removed from the law; many new barriers, inclined to discourage rather than to attract potential donors, were erected. ${ }^{2}$ The ultimate desirability of these changes depends on how one interprets the record of foundation effort in this country over the past eighty years and what one feels is an appropriate role for private philanthropy in the years ahead.

I

\section{The Structure of Foundations}

\section{A. The National Organization}

The passage of the 1969 Act forced the foundations of the country to take stock of their situation. It was clear that no organization existed that adequately represented all foundations. The existing Council on Foundations did remarkably well under the circumstances-it was staffed by one executive and a secretary. Its constituency, however, was primarily the community foundations, and its purpose was largely to maintain a close liaison with the United Community Chests and Councils of the nation-an agency now known as the United Way. Everyone realized that it would be necessary to improve dramatically the work of the Council and to provide financing adequate for the activities it would undertake on behalf of all foundations.

\footnotetext{
* Director, The Cleveland Foundation.

The statistical information in this article was taken from material presented to the Commission on Private Philanthropy and Public Needs by the Council on Foundations. The author is a member of the Executive Committee of the Council and shared with others the responsibility for producing this report. Copies are available from the Commission on Private Philanthropy and Public Needs, 1776 K Street, Washington, D.C. 20006.

1. Tax Reform Act of 1969, Pub. L. No. 91-172, 83 Stat. 487.

2. For an in-depth discussion of these tax barriers, see Worthy, The Tax Reform Act of 1969: Consequences for Private Foundations, 39 LAw \& Contemp. Prob. no. 4, at 232 (1975).
} 
The Council on Foundations now consists of a membership of 715 foundations from all sections of the country, representing about 70 per cent of the total assets of all foundations in the country. It has a strong and able staff; it publishes Foundation News, the leading magazine in the field; it maintains professional counsel in Washington; and it provides a much needed service to the many state and regional groupings of foundations that have developed in recent years. The annual meetings of the Council bring together the top leadership of foundations in the country, both at board and staff levels, and provide a forum for the exchange of ideas between foundation people and the major national leaders in the fields that normally attract most foundation support: education, the social services, health, and the arts.

A parallel development of great importance has been the strengthening of the work of the Foundation Center-a national library devoted to the publication of information about foundation activities and publisher of the main source of information about foundations, The Foundation Directory. The Center is professional in all respects, from the nature of its staff to the adoption of the most sophisticated techniques now available for managing information and making it readily available to those interested in obtaining access to such material. A monumental effort has been made to establish forty-eight branches of the Foundation Center and to interconnect these operations with the national offices in New York, operated from quarters adjoining the National Headquarters of the Council on Foundations.

This, then, is one of the major consequences of the Tax Reform Act of 1969: the foundation enterprises of the country now have the means to establish and promote good standards for governing how foundations operate; they have a forum for the exchange of views; they have sound sources of information and publications to make this information available to all; they have points of access to information that make it possible for people in the most remote locations in the country to gain the information needed to bring to foundation attention their interests in the sponsorship of a particular program. The organization of the foundations of the country into a strong national body broadly representative of all parts of the country makes it possible to repudiate the claim that such agencies are simply the pawns of the "Eastern Establishment."

\section{B. The Secondary Organizations}

Just as it was necessary to strengthen the representation of foundations at the national level and to improve the gathering and dissemination of information about foundations, so have important developments taken place at local and regional centers. Strong regional groupings now function in the Southwest, in the "Deep" South, and in New England. State conference operations, notably in Michigan and Minnesota, are relatively new, strong, and important. 
Similar developments have occurred in several of the metropolitan city areas, among them Boston, Cleveland, Chicago, Los Angeles, New York, and San Francisco.

Kansas City has long been the forerunner in its organization of a federation of private foundations to share overhead expenses and to undertake programs that are only possible if several foundations join in the required financing. The principle of the Kansas City operation has spread to many other communities in the country and seems likely to be adopted in still other places in view of the assurance that through this arrangement staff services can be provided for trusts and foundations that find it otherwise difficult to meet the requirements of the 1969 Act. $^{3}$

Only rarely did private foundations join together, prior to 1969 , to undertake ventures best developed as joint efforts: such programs are fairly common now. The Act does not proscribe joint action in any way. The logic of such activity, taking into account the need to use the limited resources of foundations with an eye toward the strategy of multiplying money and effort in new fields of endeavor or along new lines indicated by growing bodies of knowledge, gives added support to such ventures. It is also apparent that cooperative endeavor between national and regional foundations enhances the prospect for success in many activities-national foundations usually having superior resources and local groups having a more intimate knowledge of the people and conditions than any national organization could possibly develop.

\section{The Community Foundations}

Perhaps the most salient beneficiaries of the 1969 Act have been the community foundations. These agencies, now numbering 250 in the nation, are viewed by law as public charities in view of the manner in which they are organized and the public process used in selecting trustees-a majority of whom have no fiduciary responsibility for the funds administered. Moreover, the community foundations pay no excise tax; they file a single tax return for all of their member funds-in some cases running into the hundreds; and, they qualify their donors for the maximum contribution deduction.

The community foundations are growing rapidly, in part because of the dissolution of small private trusts and foundations as an alternative to meeting the complex requirements of the 1969 Act. The total assets of all community foundations in the country now exceed one billion dollars. Three of the leading ones-Cleveland, Chicago, and New York-each have holdings in excess of one hundred million dollars. Some twenty community foundations have assets in excess of twenty million dollars each.

3. Id. 
The assets of community foundations grew by 30 per cent in 1972 and by another 10 per cent in.1973. A survey carried out by the Council on Foundations for the period 1968-72 indicated that 46 per cent of the forty million dollars received by sixty foundations for this period came from the liquidation of private foundations. A second study of twenty community foundations from 1970 through 1971 indicated that sixty million dollars in new assets were added to community foundations during this period as a result of the dissolution of private foundations. Most observers believe that this trend will continue and that new community foundations will be established-some of them on a state-wide basis, along the lines of developments in New Hampshire and Oregon in recent years.

II

\section{Foundation RESOURCES}

One consequence of the reporting requirement of the Tax Reform Act of 1969 is that it is now possible to get a reasonable picture of foundation assets and the level of their annual spending. The Foundation Center estimated at the end of Calendar Year 1973 that total foundation assets in the nation were approximately $\$ 31.5$ billion and total giving of all foundations in that year was $\$ 2.36$ billion or 9.6 per cent of total private giving. These figures suggest the rather modest contribution provided by foundation grants-less than 10 per cent of all private giving, less than a fraction of one per cent of the annual appropriations of the federal government for health and welfare services alone.

A closer look at foundations in the United States indicates that there are between 28,000 and 30,000 nonoperating foundations in the country that make annual grants for research and program services of various kinds. The figures are still a bit confusing, however, until we delve even closer and discover that the overwhelming number of foundations-a figure estimated at between 26,500 and 28,500-have assets of less than one million dollars. Moreover, according to the Foundation Center Databank for Fiscal Year 1971, the average assets of foundations with property valued at less than one million dollars were $\$ 114,152$ and the total assets of all of these foundations were considerably less than the assets of the Ford Foundation. This means that a large part of the foundation wealth of the country is held by 2,370 grant-making foundations with assets of over one million dollars. As of 1971 only 180 foundations in the country had assets in excess of twenty-five million dollars. 


\section{III}

\section{The Challenges}

\section{A. Public Relations}

It may be well to note that the foundations will always have a public relations problem of some magnitude, one that is not easily resolved. Foundations supply marginal amounts of money at best; the main lines of support for various kinds of services must be from either government or from organized private giving on an annual basis-or, usually, a combination of both. Foundations operate best when they work at the "growing" edge of knowledge, when they uncover and support talent interested in finding new ways of dealing with old problems, when they experiment in the grants they make and the people they support. The foundation that must deny ninety requests for every one that is accepted-and this is a reality for most foundations-has severe limits on its ability to "win friends and influence people" even under ideal circumstances.

\section{B. Is the Tax Burden Necessary?}

The Tax Reform Act of 1969 imposed a four per cent excise tax on the investment income of foundations. In tax year 1974 this levy yielded $\$ 76,617,000 .^{4}$ This amount is far in excess of the money required to audit foundations operations-indeed, it is about four times as much as is required to finance surveillance of all tax-exempt organizations in the nation. The Internal Revenue Service expended $\$ 2.1$ million to audit foundations in 1969 , $\$ 12.3$ million in 1973 . The total cost for all exempt organizations was $\$ 7.5$ million in $1969, \$ 18.6$ million in 1973.

Quite clearly, then, the current tax on foundation income is for the purpose of producing revenue rather than to offset the cost of auditing foundation operations. As such, it simply removes money that would otherwise support charitable services into Treasury coffers. Since it is also a tax on income, it acts as a disincentive for income production on the one hand and severely penalizes those who are forced to sell securities either to meet the pay-out requirement of the Act or to meet the divestiture requirements. One of the leading executives of a major foundation recently provided an insight into how this works:

Much more money comes in than is needed for the audit function (and Treasury agrees that this is so), then charity suffers. Part of the excess which comes in is based on application of the tax to realized capital gains. In 1972, for example, we had a major secondary offering of stock, both for diversification and increased income purposes (we have never had an excess business holdings problem). The capital gain was about $\$ 125$ million and the $4 \%$ tax

\footnotetext{
4. Id. at 247 .
} 
on the capital gains portion alone was in excess of $\$ 5$ million. The income or required distributions on this amount (which had to be paid out of principal) is obviously gone forever from the charitable sector.

Attention is being focused on this matter in many quarters, including in the Treasury Department. It is to be hoped that the tax will either be reduced (to, e.g., two per cent) or a new principle, that of taxing on the basis of assets rather than income, will be adopted.

\section{The Pay-Out Requirement}

The Act imposed a minimum pay-out requirement on private foundations that will reach six per cent for tax year 1975. It requires that foundations pay out either their entire current investment yield or a fixed minimum investment return (MIR) whichever is higher. Furthermore, the Secretary of the Treasury has the power to modify the MIR on the basis of current interest rates and investment yields in relation to market conditions. ${ }^{5}$ It is not surprising that this requirement has led to an appreciable increase in the level of foundation giving since 1969 . Whether the requirement of a six per cent payout is reasonable taking into account yields from stock investment-including low as well as high profit periods-is a matter of some concern. The problem of determining the value of investment assets for which market prices are not readily available has been problematic for many foundations.

\section{Grant Restrictions}

The law now requires that grants made to other than public charities must be administered in such a manner that the granting agency assumes responsibility for program development as well as accounting by the grantee. The result has been about what anyone might expect: foundations have sharply reduced grants to other than public charities. ${ }^{6}$ Any curb on venturesome grant-making would appear to divert foundations from their unique role in American society. For if grants are to be given exclusively to public charities, why not limit private giving to such agencies? There are many difficult questions for which we have poor answers in this area, although the law as it is written does not seem to be as restrictive as some of the interpretations given it-mainly by those opposed to innovative effort. The Council on Foundations advocates that a ceiling of five thousand dollars be set below which grants would be exempt from the expenditure responsibility requirements of the Act.

\footnotetext{
5. Id. at 238 .

6. Id. at 245 .
} 


\section{E. Restrictions Against Lobbying}

Surprisingly, the restrictions in the 1969 Act against lobbying of any kind have been accepted with little question by private foundations, even though the restrictions go far beyond those applicable to public charities or to business and industry. Few foundations have ever attempted to influence legislation directly or to take a direct hand in partisan activity of any kind. The few cases that did excite Congressional interest in 1969 were enough to inspire this section of the Act, but they were hardly typical of the normal foundation approach to public questions. There will remain, however, a considerable gray area in which common sense and good judgment on all sides will be required. While the law clearly permits the support of studies that are undertaken to enlighten the public on matters of public interest, it is also apparent that most legislative proposals are preceded by some sort of study of the questions involved and by a marshalling of a case supporting such action.

\section{F. Compliance and Enforcement}

The 1969 Act provides stiff penalties for failure to comply with the law, and IRS apparently intends to enforce these provisions as evidenced by the fact that expenditures for auditing foundations have increased eight-fold since 1969. It is generally understood that the intention is to audit each private foundation every five years, and a select group of such foundations every second year. According to the recent study published by the Council on Foundations, the violations uncovered by this expanded auditing program have been minimal. The IRS has revealed that penalties assessed for the period 1970 through the first month of 1974 totalled $\$ 469,000$, distributed as follows: self-dealing, $\$ 220,000$; failure to distribute income, $\$ 131,000$; excess business holdings, $\$ 91,000$; investments jeopardizing charitable purposes, $\$ 18,000$; and taxable, $\$ 9,000 .^{7}$

\section{IV}

\section{Conclusion}

What conclusions can reasonably be drawn about the effects of the Tax Reform Act on the private foundations of this country seven years after its passage in 1969? The returns are a bit mixed, as tends to be the case with any new piece of legislation-some being very much to the good and others of doubtful benefit to anyone.

The private foundations have undergone several organizational developments in recent years which, among other things, provide assurance that the case for foundations in particular, and for private philanthropy in general,

7. Id. at 250 . 
will be presented to the general public. They now have the means for making their case heard; they have a membership that reaches into every state and to most of the large cities of the country; they have knowing counsel to work with the Treasury Department and with appropriate committees and subcommittees of the Congress; and they have initiated the arduous task of establishing liaison with the leadership of the churches and the schools and the universities and the social service agencies and such, because it is clear that donor and donee must work together for a common cause.

It was also for the best that private foundations were reminded that they function as a result of generous provisions of the tax law and that their only legitimate purpose is to serve the public interest. All private foundations got the message, certainly those which were well aware of the law's grace prior to the Act-and this would clearly be most such foundations-as well as the few foundations that tended to skirt the ragged edges of approved behavior.

But, more important than any of the details of the many questionable and problematic requirements imposed by Congress is the fact that the National Legislature has reaffirmed the legitimacy of private effort through foundations to serve public purposes. However, despite this positive aspect, there is the disturbing question of the possible effect of the 1969 Act on the establishment of new foundations. All of the odds seem stacked against such growth, given the range of disincentives built into the law. This is a problem with which all concerned must deal directly. For it is clear that should foundations face a "no growth" phenomenon, it is for the best that it be known; that the foundations fully realize what this will portend in years to come. 